IJIET, e-ISSN 2548-8430, p-ISSN 2548-8422, Vol. 2, No. 2, July 2018

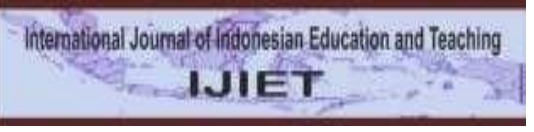

International Journal of Indonesian Education and Teaching http://e-journal.usd.ac.id/index.php/IJIET

Sanata Dharma University, Yogyakarta, Indonesia

\title{
USING EXELSA MOODLE TO DEVELOP MATHEMATICS TEACHING SKILLS AND SPIRIT IN THE MICRO TEACHING COURSE
}

\author{
Marcellinus Andy Rudhito \\ Mathematics Education Study Program, Sanata Dharma University \\ rudhito@usd.ac.id \\ https://doi.org/10.24071/ijiet.v2i2.1175 \\ Received 3 March 2018; revised 10 June 2018; accepted 30 June 2018
}

\begin{abstract}
The purposes of the implementation of digital learning resources in the Micro Teaching Course are to (i) design and implement active and constructive learning dynamics to develop students' Ignatian Pedagogy-based teaching skills by utilizing Exelsa Moodle Learning Management System; (ii) produce teachingdesign and teaching videos that students can use to develop their teaching skills.In general, the implementation of learning is about $90 \%$ in accordance with the plan. The expected final achievement is generally achieved, namely that students have good skills in managing mathematics learning in the peer teaching (Competence), have high spirit in developing teaching ability (Conscience) and have high concern in helping their friends to develop their teaching skills (Compassion). The course design, explanations and materials are communicated optimally through Exelsa Moodle. Videos from short film projects can also be utilized properly. So far, the video recording of their teaching practice are treated merely as a collection. In fact, these videos can be utilized as examples andmodels to discuss teaching skills, in terms of material mastery, delivery or class management.
\end{abstract}

Keywords: Learning Management System, Ignatian Pedagogy, Micro Teaching Course

\section{Introduction}

As prospective teachers, Mathematics Education students should developtheir teaching skills seriously. They should also be encouraged in teaching, considering they also have diverse motivations in responding to their vocation as teachers. They need to undergo training and mentoring to practice teaching with their friends in a small group. In order to do that, they need to take the Micro Teaching Course which integrates ICT in the teaching and learning activities by utilizing the Learning Management System at Sanata Dharma University, called Exelsa Moodle. The Learning Management System using Moodle is widely used in higher education institutions and gives very positive results. This can be seen inRaman, et.al., (2014), Mtebe (2015) and Rachel and Parthasarathy (2016). 
The Micro Teaching Course is a compulsory course offered to students in semester 6. In semester 7, they practice teaching in school in PPL (Field Teaching Experience). This course provides opportunities for students to practice teaching their peers, monitored and guided by the Micro Teaching lecturers. In the previous semesters, the students have been equipped with courses that support this practice, such as Learning Psychology, Learning Methods, Lesson Plans and Learning Evaluations. In this Micro Teaching Course, they practice peer teaching in a Mathematics class and by giving each other support and suggestion for improvement.

This subject is very relevant as a vehicle to improve skills, foster spirit and concern for fellow students in learning to implement the learning process. Ignatian Pedagogy-based learning which focuses on aspects of competence, conscienceand compassion (3C) is implemented. This course is believed to be able to assist students optimally in improving their skills (competence), the spirit of teaching (conscience) in an atmosphere full of concern for the development of teaching skills among the participants (compassion). The Ignatian Pedagogy Paradigm has also been applied in some college institutions and has given very satisfactory results. This can be seen in Foster (2012), Connor (2014), Vicki (2014) and Mauri, et al., (2015).

With Ignatian Pedagogy paradigm, learning is expected to be highly relevant and supportive of the vision and mission of the study program, whose vision is to be a venue for preparing candidates for professional humane Mathematics teachers. One of its missions is to prepare students to become Mathematics teacher candidates who have pedagogical, professional, personal, and social competence, and who empathize to the problems faced by learners and who appreciate plurality.

Therefore, in this course, the students will actively develop themselves to achieve the above competencies by joint learning activities in the Micro Teaching course passionately and whole-heartedly. In this semester, the Micro Teaching course will utilize the Exelsa Moodle Learning Management System to support communication, to display results and to facilitate class discussion, both between lecturer with students or student with student. Through the implementation of the learning management system in the Micro Teaching Course, students: (1) (Competence) have a qualified skill in managing mathematics learning in the scope of peer learning exercise; (2) (Conscience) have a high spirit in developing teaching skills; (3) (Compassion) have a high concern for fellow students to develop teaching skills.

The objectives of the implementation of learning with the development of Digital Learning Resources in the Micro Teaching Course are (1) to design and implement active and constructive learning dynamics to develop students' 
teaching skills based on Ignatian Pedagogy by utilizing Exelsa Moodle Learning Management Systems; and (2) produce instructional designs and teaching videos that students can use to develop their teaching skills.

The benefits of the implementation of learning with the development of Digital Learning Resources in the Micro Teaching Course are (1) to provide guidance and tools in the dynamics of learning and teaching activities, i.e. the interaction patterns between lecturers and students and among the students to develop their teaching skills; And (2) produce micro teaching videos and knowledge that can be utilized to improve teaching skills.

\section{Theory}

This course employs various learning methods such as discussion, practice and discussion of feedback. The method of discussion in learning is a way of delivering instructional materials in which teachers provide opportunities for students or groups of students to hold scientific talks to collect opinions, draw conclusions or develop alternative solutions to problems (Aqil, 2007). Discussions are held in groups as well as class discussions facilitated by lecturers. Students discuss to prepare the scheduled teaching preparation with the lecturers and their peers. Direct practice is an educational experience involving children actively in the manipulation of objects to increase knowledge or experience (Haury \& Rillero, 1994). Meinhard (Haury \& Rillero, 1994) suggests that direct practice activity is the activity of using objects, in the form of living things and inanimate objects, which are available directly for research. The student will then practice from what he has designed before. During the practice, students will be observed by lecturers. From the observation then will be given feedback. Understanding feedback according to Eggen \& Kauchak (1994) is the information provided by teachers to students about certain behaviors in order to improve students' performance.

Moodle is a course content management (CMS), first introduced by Martin Dougiamas, a computer science and teaching expert in Perth, Australia (https://docs.moodle.org/35/en/History). Moodle is an open source CMS that is currently used by universities, educational institutions, businesses and individual instructors who want to use web technology for the management of their courses. Moodle is currently used by over 2000 educational organizations around the world, including Sanata Dharma University with its Exelsa Moodle, to deliver online learning and as an enhancement to face-to-face learning.

In the design of lectures, Moodle will be used primarily as a learning management system to facilitate discussions between lecturers and students, as well as students and students, which can take place on-line outside of face-to-face meetings. In the Moodle web it is mentioned that the design and development of Moodle is guided by "social constructionist pedagogy", which is related to concepts: constructivism, constructivism, social constructivism, and connected 
and separate (https://docs.moodle.org/24/en/Philosophy). From a constructivist point of view, people actively build new knowledge because they interact with their environment. We are not just passive memory banks that absorb information, or knowledge will "infect" us just by reading something or listening to someone. Constructionism asserts that learning is very effective when building something for others to experience. It can be anything from a spoken sentence or an internet post, to more complex artifacts such as paintings, houses or software packages. Social constructivism extends constructivism in social settings, in which groups construct knowledge of each other, collaboratively create small cultural artifacts along with shared meanings. Separate Behavior is when one tries to remain on 'purpose' and 'factual', and tends to defend their own ideas by using logic to find holes in the opponents of their ideas. Connected Behavior is a more empathic approach that accepts subjectivity, seeks to listen and ask questions in an attempt to understand other points of view. Built Behavior is when a person is sensitive to both of these approaches and is able to choose one of them that suits the current situation.

\section{Method}

The method used in this activity is the development method of teaching learning ability for prospective teachers. This lesson begins with an introduction to the principles of teaching skills and managing the classroom. Activities include the practice of teaching elementary mathematics, teaching junior high school materials, preparing teaching videos and teaching high school materials. The activity plan here also includes a draft guidance and tools in dynamics during lecture activities, supported by the Exelsa Moodle learning management system.

The implementation of the learning design will be recorded, analyzed and reported descriptively qualitatively, in terms of its implementation, the results of the student's work, evaluation and reflection. In general, the data are in the form of the practice of learning, observation result of the learning practice both from the lecturer and the students, self-evaluation of students' practice and students' reflection. In general, the data will be analyzed both quantitatively and qualitatively, in terms of the design of the practice, the results of the observation of the practice of assessment. In contrast, self-evaluation and students' reflection will be used as triangulation data. Quantitative data will be presented using descriptive statistics, while qualitative descriptive data will be analyzed by reducing, classifying in the topics, synthesizing and summarizing it.

\section{Findings and Discussion}

At the beginning of the activity, lecturers prepare a one-semester activity plan in Exelsa Moodle. Lecturers give an overview of activities for one semester, which includes the form of tasks that must be generated to students. 


\section{Practice teaching with elementary school materials}

Before elementary school teaching and warming-up, students are asked to come to the front of the class introduce themselves, pretending to be new teachers. The forward sequence is shown randomly. In the checklist, the list of things is checked and written on the blackboard. Otherwise, the checking is done while the students are being observed.

In this elementary school practice, the students perform according to the order of the names in the attendance list. Each student performed for about 15 minutes, so in a two-hour course, four students perform. Students are given the freedom to choose their own topics and strategies. The schedule of students' elementary school teaching practice is uploaded to Exelsa Moodle. They first make a teaching preparation with a predefined format that the lecturer has uploaded in the Exelsa. The preparation is assisted by lecturers in the classroom or they can consult outside the classroom. Their finalized teaching preparation is uploaded at Exelsa Moodle no later than 2 hours before practice.

In this practice, lecturers make the most commentary and input. Students are occasionally given the opportunity to comment on their friends' performance, as they learn the skills of teaching directly. This comment is also uploaded in Exelsa Moodle so all students can read the comments.

After they perform, they get the recording video files of their teaching practice. They were asked to play back the video and do their self-evaluation while teaching. The format of self-evaluation has been determined by the lecturer and uploaded in the Exelsa Moodle. The self-evaluation results are required to be uploaded in Exelsa Moodle no later than 1 week after the show.

After every student finishes practicing in the elementary school teaching, they are asked to write a reflection on the perceived experience until the end of the elementary material practice. They must reflect on the changes they have felt after teaching. The reflection consists of 300 words and is uploaded before the junior high school practice begins.

\section{Practice teaching with the junior high school material}

Before teaching the junior high school materials, first the lecturer arranges the schedule based on the order, determines the observer and selects the material to be taught. The practice of teaching junior material lasts for about 30 minutes. The lecturer first uploaded the learning plan format in the Exelsa Moodle. There is one meeting in the classroom where the students jointly organize the preparation of teaching guided by the lecturer. It also explains how observers observe and comment on their performing friends. Every student who performs teaching will be observed and commented on by two students and lecturers. The observation format is uploaded in the Exelsa Moodle by the lecturer. 
Before the teaching practice, students upload the final teaching plan at least 2 hours before practice. The Exelsa Moodle facility used is a forum, to enable the students, especially observers to access it before practice. The Observations made by two students are uploaded in the Exelsa Moodle Forum. After all the students have performed, the lecturer also uploads a summary of the comments submitted online. As in the practice of elementary materials, at the end of the junior high school practice, each student writes his reflection and uploads in the ExelsaMoodle Forum so that all his friends can also read and learn from each other's experiences.

\section{Practice of Making Video}

This activity was designed because the mid tests took two weeks which did not allow for the practice of learning in the classroom. In addition, this activity is considered important and relevant to the purpose of the course. Previously they were given an explanation on how to prepare materials for filming. This is because the film making is done independently outside of college hours.

Next, the students work in groups of three, so there are 6 groups in the class. They discussed in groups about story ideas, synopsis, and scenario of films to be made and written down in a script. The movie scenario is uploaded in the Exelsa Moodle Forum. On each occasion there is a meeting in the classroom to show and discuss the results of their film making process. Feedback and suggestion from the lecturer and students are used to perfect their movie. The movies that have been viewed in terms of material, capability and time are uploaded on YouTube and the links are uploaded in the Exelsa Moodle Forum. At the end of this short film project, each student is required to write a reflection and upload it in the Exelsa Moodle.

\section{Practice teaching high school materials}

In general, the practice of teaching high school materials is similar to the practice of junior high school materials. However, there are several differences. In high school teaching practice, the order of the performing students is made not based on the order in the attendance list. The order is made based on the drawing as suggested by the students. The duration for teaching practice is 45 minutes. Comments from observers and lecturers are shorter. Self-observation is required both in elementary school and the junior high school teaching practice. In the high school teaching practice, the special reflection is directly combined with the reflection of the whole lecture activities for one semester. In general, students rate this lecture as good in the Online Evaluation in Academic Information System, with an average score of 5.7, with very positive student comments. Of the 18 students who attended the lecture, all of them were able to complete the course, in which16 students got $\mathrm{A}(89 \%)$ and 2 got $\mathrm{B}(11 \%)$. 
In general, lectures run according to plan, approximately $90 \%$ in accordance with the lesson plan. All students are enthusiastic and passionate about taking the course. The tasks are well executed and uploaded in the Exelsa Moodle relatively on time. Their teaching skills seem to show significant progress. Their concern for the progress of their friends is quite high, both as a student and as an observer when commenting and giving feedback.

\section{Practice teaching with elementary school materials}

When the students introduce themselves as teachers, quite a lot of dynamics happened. Some of them are used to talking in public, some are still nervous, their voice is still too loud, and the writing is not big enough. Some of his bearing are funny, cheerful, hesitant, and so forth. One of the introductory reflection fragments is as follows:

"Several hours passed, I passed everything well. Our introduction is through "acting" as a new teacher. The activity is quite unique and creative to me, in this way the awkwardness that once was like a wall of separation has begun to crumble. Laughter began our intimacy. Moreover, I acknowledge that the lecturers who are teaching this course are powerful enough and capable enough to embrace us to remove the fearful initial tension. "

Here students also began to enjoy their role as students. Things that did not fit were directly commented by lecturers in order for students to be more skilled in managing the class and teaching. Teaching skills are studied from direct practical cases from students.

When students prepared lesson plans, they seemed quite enthusiastic. They enthusiastically discussed the materials and learning approaches to be used, whether with lecturers or students. They were asked to use props available in the micro teaching room.

Students who became students were also quite supportive in the development of their friends' teaching skills. They could pretend as students naturally, although they learned many things from their friends' teaching skills. Here's the reflection from one of the students:

"I was nervous and afraid before the elementary school practice. I was afraid of running out of materials. I also feared that my friends did not want to work together. I prepared everything hastily and with a limited time, I finished the demonstration tools. I had alternative props to be used because I was confused which props were easy to understand and did not require much time. And it was stressful to see a friend who took the first turns run out of time. They panicked and the sound of the bell was a startling. After the practice, I just realized that being a teacher is not easy because I have to prepare everything and teach as well as control the class because students constantly seek attention from the teacher. The change that I felt was that I became less nervous when speaking in front of 
the class, but I became a little bit confused because I did not want to be a teacher. I am also happy with this Micro Teaching course because besides being able to learn to be a good teacher we can also learn from any mistakes, shortcomings and evaluation from lecturers for us or other friends so that we do not repeat the same mistakes again and always strive to become professional teachers."

\section{Practice teaching junior high school materials}

In this practice teaching, students kept the spirit in the preparation. They are quite solid to help each other. Although some students belonged to different classes and they rarely met, they were quite easy to assimilate and accept. Different abilities among students are utilized so that they could learn from each other. Students who spoke softly learned from whose who spoke loudly. Students who lack selfconfidence and courage could learn from those who were brave and assertive.

During the observation of their friends' practice teaching, the students were quite serious in giving comments and suggestions to improve their friends' performance. Likewise, friends must accept the feedback and suggestion gratefully and with an open heart. The suggestion and feedback must also be submitted, uploaded, and discussed in the Exelsa Moodle Forum. The Practice of Making

\section{Video Learning}

From their reflection in general students initially hesitate in accepting this task, because most of them did not have any experience in making a movie. During the briefing, lecturers boosted the students' spirit that they could do it. Through systematic steps and the support from the material resources, students do the task enthusiastically and whole-heartedly.

In the process of making the video, students discussed very intensely in the group. In the initial viewing discussion, they also gave each other feedback for the improvement of the film. Lecturers continue to encourage, suggest and propose a solution of the existing problem. One piece of reflection in filmmaking is as follows:

"From making this short film I get a lot of benefits, especially when it comes to prospective teachers. I became more interested in how to make the film, from the beginning until the end. However, during the filming I still had to ask for help here and there, and I had to repeat, edit, take back, and so on. So the spirit must be maintained, never give up despite failing continuously. I also learned that being a teacher is not only teaching in front of the class, being an expert in the material, but also being a creative teacher. The benefits may not be seen now. Probably, when one has become a teacher will he/she see the benefits. The most important thing is that the student has first-hand experiences in making the film. But the drawback is of the limited time. In reality, teachers' jobs cover not only teaching but also school management which takes so much time." 


\section{Practice teaching high school materials}

In practice, this is the culmination of their skills that have been quite honed in the previous practices. The material they teach is also quite difficult and the time they spend is also quite long. In general, their ability and teaching skills show good progress.

Their enthusiasm either as teachers, students or observers does not recede; they remain passionate and enthusiastic in displaying their best abilities. Some students still have to deal with lack of material understanding. This is reasonable, since the material mastery when teaching is clearly required over a period of time. One of students' final reflection regarding the teaching of high school materials is as follows:

"After a special round in mini drama was completed, the final round was announced. It was high school teaching practice. I no longer play a role in the final scene. The initial state began to change, I felt I was among family. I could adapt very well. There was no more awkwardness that I experienced until the process which I called "Mini Drama" was over. I get everything in this subject, be it science, advice and family. I'm ready to be a teacher and have a dynamic with anyone, anytime and anywhere. This is the path I choose. I have completed one ofthe short mini dramas of my life, and now I am ready for other amazing dramas that are waiting for me to play a role in it "

Thus, in general, the lecture has been run as planned and the goals determined have also been generally achieved, from the aspects of Competence, Conscience and Compassion (3C).

\section{Conclusion}

In general, the implementation of learning is about $90 \%$ in accordance with the plan. The expected final achievement is generally achieved, namely that students have good skills in managing mathematics learning in the scope ofCompetence, have high spirit in developing teaching ability (Conscience) and have high concern in helping their friends to develop their teaching skills (Compassion). The results of the students' evaluation in general are also good, with an average score of 5.8 and with very positive comments. The grades obtained by students are also very good, in which $89 \%$ earned A and $11 \%$ got a B.The use of Exelsa Moodle was also quite optimal, in which the course design and explanations and materials used in the lectures could be well communicated. Videos from short film projects with mathematical themes could also be produced properly and were uploaded on Youtube.

In this lecture, the video recording of the teaching practice still tends to be used as a collection in the student laboratory. Actually, these videos can beutilized as examples in the discussion of teaching skills, in terms of material mastery, delivery or class management. 


\section{References}

Caruana, V. (2014). Using the Ignatian pedagogical paradigm to frame the reflective practice of special education teacher candidates. Jesuit Higher Education, 3(1), 8.

Connor, K.R. (2014). Accompanying the student: The Ignatian pedagogical paradigm and prior learning. Jesuit Higher Education, 3(1), 40-47.

Eggen, P.D. \& Kauchak, D.P. (1994). Strategies for teachers. Boston: Allyn and Bacon.

Foster, S.L. (2012). Engaging and empowering preservice teachers through Ignatian and critical pedagogy: Examples from the classroom. Jesuit Higher Education, $1(1), 11$.

Haury, D. L. \& Rillero, P. (1994). Perspectives of hands-on science teaching. Columbus, OH: ERIC Clearinghouse for Science, Mathematics, and Environmental Education, Columbus, Ohio.

Mauri, A.J., Figueiredo, J.N., \& Rashford, N.S. (2015). Ignatian pedagogy in the strategy classroom: Experience, reflection and action towards better managerial decisions. Journal of Jesuit Business Education, 6(1).

Mtebe, J.S. (2015). Learning management system success: Increasing learning management system usage in higher education in sub-Saharan Africa. International Journal of Education and Development using Information and Communication Technology (IJEDICT), 11(2), 51-64.

Rachel, V. \& Parthasarathy, M. (2016). Learning management system using open source moodle for computer science students in higher educational institute. International Journal of Computer Science \& Engineering Technology (IJCSET). 7(1).

Raman, A., Don, Y., Khalid, R. \& Rizuan, M. (2017). Usage of learning management system (moodle) among postgraduate students: UTAUT model. Asian Social Science, 10(14).

Zainal, A. (2007). Model-model mengajar. Bandung: CV. Diponegoro. 